\title{
Phthalide derivatives with antifungal activities against the plant pathogens isolated from the liquid culture of Pestalotiopsis photiniae
}

\author{
Xiao-Long Yang ${ }^{1,2}$, Su Zhang ${ }^{2}$, Qiong-Bo $\mathrm{Hu}^{3}$, Du-Qiang Luo ${ }^{1}$ and Yan Zhang ${ }^{2}$ \\ Three new phthalide derivatives (1-3) named 5-(3'-methyl-2'-butenyl)-2-hydroxy-3-methoxy-4-methylbenzoic acid (1), 5-(3'-carboxyl- \\ $3^{\prime}$-methyl-2E-allyloxy)-3-methoxy-4-methylphthalide (2) and 5-(3',3'-dimethylallyloxy)-2-methoxycarbonyl-3-methoxy-4-methylbenzoic \\ acid (3) together with six known phthalide derivatives named 5-(3',3'-dimethylallyloxy)-3-methoxy-4-methylphthalide (4), \\ zinnimidine (5), 5-(3',3'-dimethylallyloxy)-3-methoxy-4-methylphthalide (6), 5-(3',3'-dimethylallyloxy)-3-methoxy-4-methylphthalic \\ acid (7), zinniol anhydride (8) and porriolide (9) were isolated from the liquid culture of the plant endophytic fungus \\ Pestalotiopsis photiniae isolated from the Chinese Podocarpaceae plant Podocarpus macrophyllus. Their structures were elucidated \\ by extensive spectroscopic analysis. Compounds 1-9 displayed significant antifungal activities against three plant pathogens. \\ The Journal of Antibiotics (2011) 64, 723-727; doi:10.1038/ja.2011.82; published online 14 September 2011
}

Keywords: antifungal activity; Pestalotiopsis photiniae; Podocarpus macrophyllus; phthalide derivatives; plant pathogen

\section{INTRODUCTION}

Fungi of the genus Pestalotiopsis (Amphisphaeriaceae) are known as endophytes of tropical higher plants, which are common in their distribution, and many are saprobes, while others are either pathogenic or endophytic to living plants. ${ }^{1}$ Since the discovery of the anticancer agent taxol from an endophytic fungal strain of the genus Pestalotiopsis, ${ }^{2-3}$ interest in searching for bioactive compounds from this fungal genus has increased considerably. Up to date, about 300 species of the genus Pestalotiopsis have been recorded in China, but only about $10 \%$ of these species referred to chemical investigation led to the isolation of a variety of bioactive metabolites. ${ }^{4-9}$

Our previous investigation of Pestalotiopsis photiniae grown in the liquid culture has led to the isolation of several compounds, such as dihydroberkleasmin $\mathrm{A},{ }^{10}$ 10-norparvulenone $\mathrm{e}^{11}$ and zinniol-related phytotoxins. ${ }^{12}$ Further to search for the minor active components, the fungus $P$. photiniae was refermented in a larger scale using the liquid fermentation culture. Its ethyl acetate extract displayed significant antifungal activities against three plant pathogens, Fusarium graminearum, Botrytis cinerea and Phytophthora nicotianae. Bioassay-directed fractionation of this extract has led to the isolation of nine phthalide derivatives (1-9) including three new ones (1-3). Compounds (1-9) displayed significant antifungal activities against the above three plant pathogens (Figure 1). Details of the isolation, structure elucidation and antifungal activity of these compounds are reported herein.

\section{MATERIALS AND METHODS}

General experimental procedures

Optical rotations: Perkin-Elmer 341 spectropolarimeter (Perkin-Elmer, Boston, MA, USA). IR spectra: Perkin-Elmer 577 spectrometer; KBr pellets; in $\mathrm{cm}^{-1}$. NMR spectra: Bruker AM-600 spectrometer (Bruker, Bremen, Germany); $\delta$ in p.p.m., $J$ in $\mathrm{Hz} ; \mathrm{Me}_{4} \mathrm{Si}$ as internal standard. FT-MS spectra: Bruker apex-ultra 7.0T spectrometer in $\mathrm{m} / \mathrm{z}$. Column chromatography (CC): silica gel $(200 \sim 300$ mesh, Yantai Zhi Fu chemical, People's Republic of China), TLC: silica gel $\mathrm{GF}_{254}$ plates (Yantai Zhi Fu chemical, People's Republic of China) and Sephadex LH-20 gel (25 100 $\mu \mathrm{m}$, GE Healthcare, Uppsala, Sweden).

\section{Fungal material and cultivation conditions}

Pestalotiopsis photiniae was isolated from the branch of Podocarpus macrophyllus in Hainan, People's Republic of China, in April 2008, and identified by Professor Jing-Ze Zhang, Institute of Biotechnology, Zhejiang University, which was assigned the accession number L328 in the culture collection at College of Life Science, Hebei University. The fungal strain was cultured on slants of potato dextrose agar (modified) at $28^{\circ} \mathrm{C}$ for 7 days, and then inoculated into $500 \mathrm{ml}$ Erlenmeyer flask containing $100 \mathrm{ml}$ of modified potato dextrose agar medium (glucose $20 \mathrm{~g}$, potato (peeled) $200 \mathrm{~g}, \mathrm{KH}_{2} \mathrm{PO}_{4} 3 \mathrm{~g}, \mathrm{MgSO}_{4} 1.5 \mathrm{~g}$, citric acid $0.1 \mathrm{~g}$ and thiamin hydrochloride $10 \mathrm{mg}$ in 1.01 deionized $\mathrm{H}_{2} \mathrm{O}$ ). The final $\mathrm{pH}$ of the media was adjusted to 6.5 before sterilization. After 7 days of incubation at $28^{\circ} \mathrm{C}$ on rotary shakers at $150 \mathrm{rpm}, 25 \mathrm{ml}$ of culture liquid were transferred as seed into each $1000 \mathrm{ml}$ Erlenmeyer flask containing $250 \mathrm{ml}$ of modified potato dextrose agar medium, and fermentation was carried out on a shaker for 30 days.

\footnotetext{
${ }^{1}$ Key Laboratory of Pharmaceutical Chemistry and Molecular Diagnosis of Ministry of Education and College of Life Science, Hebei University, Baoding, PR China; ${ }^{2}$ College of Pharmaceutical Science, Hebei University, Baoding, PR China and ${ }^{3}$ College of Natural Resources and Environment, South China Agricultural University, Guangzhou, PR China Correspondence: Dr D-Q Luo, Key Laboratory of Pharmaceutical Chemistry and Molecular Diagnosis of Ministry of Education and College of Life Science, Hebei University, Baoding 071002, PR China

E-mail: Duqiangluo@163.com

or Dr Q-B Hu, College of Natural Resources and Environment, South China Agricultural University, 483\#, Wushan Road, Tianhe, Guangzhou 510642, PR China. E-mail: hqbscau@126.com
}

Received 5 April 2011; revised 21 July 2011; accepted 12 August 2011; published online 14 September 2011 
<smiles>CC(C)=CCc1cc(C(=O)O)c(O)c(O)c1C</smiles>

1<smiles>COc1c(C)c(OCC=C(C)C)cc2c1COC2=O</smiles><smiles>COc1c(C)c(OCC=C(C)C)cc(C(=O)O)c1C(=O)O</smiles><smiles>COc1c(C)c(OC/C=C(\C)C(=O)O)cc2c1[CH]CC2=O</smiles><smiles>COc1c(C)c(OCC=C(C)C)cc2c1CNC2=O</smiles><smiles>COc1c(C)c(OCC=C(C)C)cc2c1C(=O)OC2=O</smiles><smiles>COC(=O)c1c(C(=O)O)cc(OCC=C(C)C)c(C)c1OC</smiles>

3<smiles>COc1c(C)c(OCC=C(C)C)cc2c1C(=O)OC2</smiles><smiles>COc1c(C)c(O)cc2c1COC2=O</smiles>

8

9

Figure 1 The structures of compounds 1-9.

\section{Extraction and isolation}

The culture broth (60l) was extracted three times with ethyl acetate (with each soaking for 2 days), and the organic layer was concentrated in vacuo to yield a brown oily residue $(18.0 \mathrm{~g})$. This residue was subjected to a silica gel CC with a gradient elution of petroleum ether/acetone (100:0, 98:2, 95:5, 90:10, 80:20 and 50:50 (v/v)) to obtain six fractions (Fr.) 1-6. Fr. 4 (2.3 g) eluted with petroleum ether/acetone (90:10) was repeatedly purified by CC (silica gel; petroleum ether/acetone 50:1 (v/v)) and Sephadex LH-20 (chloroform/methanol, 1:1) to afford compound $4(10 \mathrm{mg})$. Fr. $5(3.0 \mathrm{~g})$ eluted with petroleum ether/acetone (80:20) was further fractionated by silica gel CC using petroleum ether/acetone gradient elution (from 20:1 to 1:1, v/v) to obtain six Fr., 5.1-5.6. The Fr. 5-2 $(210 \mathrm{mg})$ eluted with petroleum ether/acetone $(10: 1, \mathrm{v} / \mathrm{v})$ was further purified by repeated CC (silica gel; petroleum ether/ ethyl acetate $8: 1(\mathrm{v} / \mathrm{v}))$, Sephadex LH-20 (chloroform/methanol, 1:1) and preparative TLC (petroleum ether/ethyl acetate, 1:4) to afford compounds $5(5 \mathrm{mg}), 7(7 \mathrm{mg})$ and $8(11 \mathrm{mg})$. Compounds $1(2 \mathrm{mg})$ and 6 (4 mg) were obtained from the Fr. 5-3 (150 mg) eluted with petroleum ether/acetone $(8: 1, \mathrm{v} / \mathrm{v})$ after repeated CC (silica gel; chloroform/acetone 20:1 (v/v)), Sephadex LH-20 (chloroform/methanol, 1:1) and preparative TLC (chloroform/acetone, 6:1). The Fr. 5-4 (160 mg) eluted with petroleum ether/acetone $(6: 1, \mathrm{v} / \mathrm{v})$ was subsequently purified by repeated CC (silica gel; petroleum ether/ethyl acetate 12:1 (v/v)), Sephadex LH-20 (acetone) and preparative TLC (petroleum ether/acetone, 1:1) to afford compounds $2(4 \mathrm{mg}), 3(3 \mathrm{mg})$ and $\mathbf{9}(8 \mathrm{mg})$.

5-(3'-Methyl-2'-butenyl)-2-hydroxy-3-methoxy-4-methylbenzoic acid (1): isolated as white powder. IR $(\mathrm{KBr}) \mathrm{v}_{\max }: 3406(\mathrm{OH}), 1699(\mathrm{C}=\mathrm{O})$ and 1557 $(\mathrm{C}=\mathrm{C}) \mathrm{cm}^{-1} \cdot{ }^{1} \mathrm{H}\left(600 \mathrm{MHz}, \mathrm{CDCl}_{3}\right)$ and ${ }^{13} \mathrm{C} \mathrm{NMR}\left(150 \mathrm{MHz}, \mathrm{CDCl}_{3}\right)$ : see Table 1. Positive ion HRAPCIMS $[\mathrm{M}+\mathrm{H}]^{+} m / z 251.12781$ (calcd for $\mathrm{C}_{14} \mathrm{H}_{19} \mathrm{O}_{4}$, 251.12779).

5-(3'-Carboxyl-3'-methyl-2E-allyloxy)-3-methoxy-4-methylphthalide (2): isolated as white powder. IR $(\mathrm{KBr}) \mathrm{v}_{\max }: 3227(\mathrm{OH}), 1740,1780(\mathrm{C}=\mathrm{O})$ and 1618 $(\mathrm{C}=\mathrm{C}) \mathrm{cm}^{-1} \cdot{ }^{1} \mathrm{H}\left(600 \mathrm{MHz}, \mathrm{CDCl}_{3}+\mathrm{CD}_{3} \mathrm{OD}\right)$ and ${ }^{13} \mathrm{C} \mathrm{NMR}(150 \mathrm{MHz}$, $\mathrm{CDCl}_{3}+\mathrm{CD}_{3} \mathrm{OD}$ ): see Table 1 . Positive ion HRESIMS $[\mathrm{M}+\mathrm{H}]^{+} \mathrm{m} / \mathrm{z}$ 293.10185 (calcd for $\mathrm{C}_{15} \mathrm{H}_{17} \mathrm{O}_{6}, 293.10196$ ).

5-(3',3'-Dimethylallyloxy)-2-methoxycarbonyl-3-methoxy-4-methylbenzoic acid (3): isolated as white powder. IR $(\mathrm{KBr}) \mathrm{v}_{\max }: 3431(\mathrm{OH}), 1680,1720$ $(\mathrm{C}=\mathrm{O})$ and $1600(\mathrm{C}=\mathrm{C}) \mathrm{cm}^{-1} \cdot{ }^{1} \mathrm{H}\left(600 \mathrm{MHz}, \mathrm{CDCl}_{3}\right)$ and ${ }^{13} \mathrm{C}$ NMR $\left(150 \mathrm{MHz}, \mathrm{CDCl}_{3}\right)$ : see Table 1. Positive ion HRESIMS $[\mathrm{M}+\mathrm{H}]^{+} \mathrm{m} / \mathrm{z}$ 309.13338 (calcd for $\mathrm{C}_{16} \mathrm{H}_{21} \mathrm{O}_{6}, 309.13326$ ).

5-(3',3'-Dimethylallyloxy)-3-methoxy-4-methylphthalide (4): isolated as white powder. ${ }^{1} \mathrm{H}\left(600 \mathrm{MHz}, \mathrm{CDCl}_{3}\right) \delta 7.08(1 \mathrm{H}, \mathrm{s}$ and $\mathrm{H}-6), 5.83(2 \mathrm{H}, \mathrm{s}$ and $\mathrm{H}-8)$,
Table $1{ }^{1} \mathrm{H}(600 \mathrm{MHz})$ and ${ }^{13} \mathrm{C}$ NMR $(150 \mathrm{MHz})$ data for compounds 1-3

\begin{tabular}{|c|c|c|c|c|c|c|}
\hline \multirow[b]{2}{*}{ No. } & \multicolumn{2}{|l|}{1} & \multicolumn{2}{|c|}{2} & \multicolumn{2}{|l|}{3} \\
\hline & $\delta_{H}$ & $\delta_{C}$ & $\delta_{H}$ & $\delta_{C}$ & $\delta_{H}$ & $\delta_{C}$ \\
\hline 1 & & 131.5 (s) & & 125.9 (s) & & 125.6 (s) \\
\hline 2 & & 152.9 (s) & & 128.6 (s) & & 124.7 (s) \\
\hline 3 & & 157.8 (s) & & 153.1 (s) & & $158.2(\mathrm{~s})$ \\
\hline 4 & & $122.2(\mathrm{~s})$ & & 125.9 (s) & & 128.7 (s) \\
\hline 5 & & 126.8 (s) & & 158.6 (s) & & 159.8 (s) \\
\hline 6 & 6.85 (s) & 112.4 (d) & 7.03 (s) & 101.3 (d) & 7.32 (s) & $109.4(d)$ \\
\hline 7 & & 175.0 (s) & & 172.1 (s) & & $171.2(\mathrm{~s})$ \\
\hline 8 & & & $5.44(\mathrm{~s})$ & $69.0(\mathrm{t})$ & & 169.3 (s) \\
\hline 9 & 3.55 (s) & $60.3(q)$ & 3.91 (s) & 59.0 (q) & 3.80 (s) & $62.3(q)$ \\
\hline 10 & 2.16 (s) & $9.5(q)$ & 2.21 (s) & $9.4(q)$ & 2.21 (s) & 9.7 (q) \\
\hline $1^{\prime}$ & $3.41(\mathrm{~d}, 4.8)$ & $26.0(t)$ & 4.80 (br. s) & $66.0(t)$ & $4.60(\mathrm{~d}, 6.6)$ & $65.5(t)$ \\
\hline $2^{\prime}$ & 5.01(br. s) & $124.5(d)$ & 6.94 (br. s) & 136.0 (d) & 5.47 (br. s) & 119.2 (d) \\
\hline 3' & & 130.9 (s) & & $130.4(\mathrm{~s})$ & & 138.9 (s) \\
\hline $4^{\prime}$ & $1.25(\mathrm{~s})$ & $17.7(q)$ & & $169.4(\mathrm{~s})$ & $1.80(\mathrm{~s})$ & $25.8(q)$ \\
\hline $5^{\prime}$ & $1.57(\mathrm{~s})$ & $25.4(q)$ & $1.93(\mathrm{~s})$ & $12.6(q)$ & 1.77 (s) & $18.3(q)$ \\
\hline $8-\mathrm{OCH}_{3}$ & & & & & 3.92 (s) & $52.7(q)$ \\
\hline
\end{tabular}

aCompounds 1 and $\mathbf{3}$ were measured in $\mathrm{CDCl}_{3}$; compound 2 was measured in $\mathrm{CDCl}_{3}+\mathrm{CD}_{3} \mathrm{OD}$.

$3.88(3 \mathrm{H}, \mathrm{s}$ and $\mathrm{H}-9), 2.20(3 \mathrm{H}, \mathrm{s}$ and $\mathrm{H}-10), 4.56(2 \mathrm{H}, \mathrm{d}, J=6.7 \mathrm{~Hz}$ and $\mathrm{H}-1)$, $5.47(1 \mathrm{H}, \mathrm{t}, J=6.7,12.6 \mathrm{~Hz}$ and $\mathrm{H}-2), 1.80(3 \mathrm{H}, \mathrm{s}$ and $\mathrm{H}-4)$ and $1.75(3 \mathrm{H}, \mathrm{s}$ and H-5). ${ }^{13} \mathrm{C}$ NMR (150 MHz, CDCl $) \delta 127.9$ (s, C-1), 124.7 (s, C-2), 159.2 (s, C3), 125.6 (s, C-4), 152.8 (s, C-5), 101.8 (d, C-6), 171.1 (s, C-7), 68.3 (t, C-8), 59.2 (q, C-9), 9.7 (q, C-10), 65.8 (t, C-1), 119.3 (d, C-2), 138.1 (s, C-3), 25.7 (q, C-4) and 18.3 (q, C-5). It was identified as 5-(3',3'-dimethylallyloxy)3-methoxy-4-methylphthalide by comparison of the spectral data with the literature. $^{14}$

Zinnimidine (5): isolated as white powder. ${ }^{1} \mathrm{H}\left(600 \mathrm{MHz}, \mathrm{CDCl}_{3}\right) \delta 7.10$ $(1 \mathrm{H}, \mathrm{s}$ and $\mathrm{H}-6), 4.60(2 \mathrm{H}, \mathrm{s}$ and $\mathrm{H}-8), 3.87(3 \mathrm{H}, \mathrm{s}$ and $\mathrm{H}-9), 2.23(3 \mathrm{H}, \mathrm{s}$ and $\mathrm{H}-10), 4.58(2 \mathrm{H}, \mathrm{d}, J=6.7 \mathrm{~Hz}$ and $\mathrm{H}-1), 5.18(1 \mathrm{H}, \mathrm{t}, J=6.7,12.6 \mathrm{~Hz}$ and $\mathrm{H}-2)$, $1.80(3 \mathrm{H}, \mathrm{s}$ and $\mathrm{H}-4)$ and $1.74(3 \mathrm{H}, \mathrm{s}$ and $\mathrm{H}-5) .{ }^{13} \mathrm{C} \mathrm{NMR}\left(150 \mathrm{MHz}, \mathrm{CDCl}_{3}\right) \delta$ 130.8 (s, C-1), 126.2 (s, C-2), 158.7 (s, C-3), 123.9 (s, C-4), 153.7 (s, C-5), 101.2 
(d, C-6), 171.2 (s, C-7), 43.9 (t, C-8), 59.8 (q, C-9), 9.6 (q, C-10), 65.7 (t, C-1), 119.6 (d, C-2), 137.8 (s, C-3), 25.8 (q, C-4) and 18.3 (q, C-5). It was identified as zinnimidine by comparison of the spectral data with the literature. ${ }^{14}$

5-(3',3'-Dimethylallyloxy)-3-methoxy-4-methylphthalide (6): isolated as white powder. ${ }^{1} \mathrm{H}\left(600 \mathrm{MHz}, \mathrm{CDCl}_{3}\right) \delta 6.62(1 \mathrm{H}, \mathrm{s}$ and $\mathrm{H}-6), 5.18(2 \mathrm{H}, \mathrm{s}$ and $\mathrm{H}-7)$, $4.03(3 \mathrm{H}, \mathrm{s}$ and $\mathrm{H}-9), 2.15(3 \mathrm{H}, \mathrm{s}$ and $\mathrm{H}-10), 4.59(2 \mathrm{H}, \mathrm{d}, J=6.6 \mathrm{~Hz}$ and $\mathrm{H}-1)$, $5.49(1 \mathrm{H}, \mathrm{t}, J=6.6,13.2 \mathrm{~Hz}$ and $\mathrm{H}-2), 1.81(3 \mathrm{H}, \mathrm{s}$ and $\mathrm{H}-4)$ and $1.75(3 \mathrm{H}, \mathrm{s}$ and $\mathrm{H}-5) .{ }^{13} \mathrm{C}$ NMR $\left(150 \mathrm{MHz}, \mathrm{CDCl}_{3}\right) \delta 109.5$ (s, C-1), 148.1 (s, C-2), 163.6 (s, C3), 120.8 (s, C-4), 157.8 (s, C-5), 99.5 (d, C-6), 68.7 (t, C-7), 169.0 (s, C-8), 62.1 (q, C-9), 8.7 (q, C-10), 65.8 (t, C-1), 118.9 (d, C-2), 138.6 (s, C-3), 25.8 (q, C4) and 18.3 (q, C-5). It was identified as 5-( $3^{\prime}, 3^{\prime}$-dimethylallyloxy)-3-methoxy4-methylphthalide by comparison of the spectral data with the literature. ${ }^{14}$

5-(3',3'-Dimethylallyloxy)-3-methoxy-4-methylphthalic acid (7): isolated as white powder. ${ }^{1} \mathrm{H}\left(600 \mathrm{MHz}, \mathrm{CD}_{3} \mathrm{OD}\right) \delta 7.32(1 \mathrm{H}, \mathrm{s}$ and $\mathrm{H}-6), 3.78(3 \mathrm{H}, \mathrm{s}$ and $\mathrm{H}-9), 2.18$ (3H, s and $\mathrm{H}-10), 4.63(2 \mathrm{H}, \mathrm{d}, J=6.6 \mathrm{~Hz}$ and $\mathrm{H}-1), 5.47(1 \mathrm{H}, \mathrm{t}$, $J=6.6,12.0 \mathrm{~Hz}$ and $\mathrm{H}-2), 1.79(3 \mathrm{H}, \mathrm{s}$ and $\mathrm{H}-4)$ and $1.78(3 \mathrm{H}, \mathrm{s}$ and $\mathrm{H}-5) .{ }^{13} \mathrm{C}$ NMR (150 MHz, CD 3 OD) $\delta 127.9$ (s, C-1), 126.7 (s, C-2), 159.3 (s, C-3), 125.5 (s, C-4), 157.2 (s, C-5), 109.8 (d, C-6), 172.0 (s, C-7), 168.4 (s, C-8), 66.5 (q, C9), 9.7 (q, C-10), 62.6 (t, C-1), 120.7 (d, C-2), 139.3 (s, C-3), 25.8 (q, C-4) and 18.3 (q, C-5). It was identified as 5-( $3^{\prime}, 3^{\prime}$-dimethylallyloxy)-3-methoxy-4methylphthalic acid by comparison of the spectral data with the literature. ${ }^{15}$

Zinniol anhydride (8): isolated as white powder. ${ }^{1} \mathrm{H}\left(600 \mathrm{MHz}, \mathrm{CDCl}_{3}\right) \delta$ $7.15(1 \mathrm{H}, \mathrm{s}$ and H-6), 4.16 (3H, s and H-9), $2.20(3 \mathrm{H}, \mathrm{s}$ and $\mathrm{H}-10), 4.68(2 \mathrm{H}, \mathrm{d}$, $J=6.6 \mathrm{~Hz}$ and $\mathrm{H}-1), 5.47(1 \mathrm{H}, \mathrm{t}, J=6.6,12.6 \mathrm{~Hz}$ and $\mathrm{H}-2), 1.78(3 \mathrm{H}, \mathrm{s}$ and $\mathrm{H}-4)$ and $1.82(3 \mathrm{H}, \mathrm{s}$ and $\mathrm{H}-5) .{ }^{13} \mathrm{C} \mathrm{NMR}\left(150 \mathrm{MHz}, \mathrm{CDCl}_{3}\right) \delta 139.6(\mathrm{~s}, \mathrm{C}-1), 128.3$ (s, C-2), 160.9 (s, C-3), 112.1 (s, C-4), 157.9 (s, C-5), 103.1 (d, C-6), 164.5 (s, C-7), 163.5 (s, C-8), 66.4 (q, C-9), 9.7 (q, C-10), 62.3 (t, C-1), 118.2 (d, C-2), 131.9 (s, C-3), 25.8 (q, C-4) and 18.4 (q, C-5). It was identified as zinniol anhydride by comparison of the spectral data with the literature. ${ }^{16}$

Porriolide (9): isolated as white powder. ${ }^{1} \mathrm{H}\left(600 \mathrm{MHz}, \mathrm{CD}_{3} \mathrm{OD}\right) \delta 6.93(1 \mathrm{H}$, s and $\mathrm{H}-6), 5.47(2 \mathrm{H}, \mathrm{s}$ and $\mathrm{H}-8), 3.91(3 \mathrm{H}, \mathrm{s}$ and $\mathrm{H}-9)$ and $2.16(3 \mathrm{H}$, s and $\mathrm{H}-$ 10). ${ }^{13} \mathrm{C}$ NMR $\left(150 \mathrm{MHz}, \mathrm{CD}_{3} \mathrm{OD}\right) \delta 127.6$ (s, C-1), 124.9 (s, C-2), 159.6 (s, C3), 125.6 (s, C-4), 154.7 (s, C-5), 105.3 (d, C-6), 173.8 (s, C-7), 70.1 (t, C-8), 59.6 (q, C-9) and 9.8 (q, C-10). It was identified as porriolide by comparison of the spectral data with the literature. ${ }^{17}$

Antifungal assays MIC of the compounds (1-9) against fungi were determined in a 96-well microtitre dish using a method modified from Nair et al. ${ }^{13}$. The inocula used in this test were a zoospore suspension $\left(10^{6}\right.$ zoospores $\left.\mathrm{ml}^{-1}\right)$ of Phytophthora nicotianae, spore suspensions of Fusarium graminearum and Botrytis cinerea $\left(10^{6}\right.$ spores $\left.\mathrm{ml}^{-1}\right)$. To each well $10 \mu \mathrm{l}$ of suspension containing $1 \mu$ l of potato dextrose broth (PDB, Difco, Becton, Dickinson and Company, Franklin Lakes, NJ, USA) was added amended with compounds 1-9 in the range $0-50 \mathrm{mgl}^{-1}$, and ketoconazole was used as the positive control. The inoculated well plates were incubated at $28( \pm 1)^{\circ} \mathrm{C}$ on a rotary shaker at

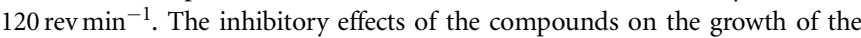
test microorganisms were evaluated after incubation for 2-4 days. The lowest concentration of the compounds that completely inhibited the growth of the microorganism was considered to be minimum inhibitory.

\section{RESULTS AND DISCUSSION}

Compound 1 was obtained as white powder. HRAPCIMS of $\mathbf{1}$ indicated a molecular formula of $\mathrm{C}_{14} \mathrm{H}_{18} \mathrm{O}_{4}\left([\mathrm{M}+\mathrm{H}]^{+}\right.$at $m / z$ 251.12781, calcd for $\left.\mathrm{C}_{14} \mathrm{H}_{19} \mathrm{O}_{4}, 251.12779\right)$ with six degrees of unsaturation. This was corroborated by the ${ }^{13} \mathrm{C}$ NMR (DEPT)
(Table 1), which displayed 14 signals for the carbons including four methyl carbons $\left(\delta_{C} 60.3(\mathrm{q}), 25.4(\mathrm{q}), 17.7(\mathrm{q})\right.$ and $\left.9.5(\mathrm{q})\right)$, one carboxyl group $\left(\delta_{C} 175.0(\mathrm{~s})\right)$, one trisubstituted double bond $\left(\delta_{C}\right.$ $124.5(\mathrm{~d}), 130.9(\mathrm{~s}))$, one pentasubstituted aromatic group $\left(\delta_{C} 157.8\right.$ (s), 152.9 (s), $131.5(\mathrm{~s}), 126.8(\mathrm{~s}), 122.2(\mathrm{~s})$ and $112.4(\mathrm{~d}))$ and one methylene carbon $\left(\delta_{C} 26.0(\mathrm{t})\right)$. Analysis of the ${ }^{1} \mathrm{H}$ NMR spectrum (Table 1) indicated the presence of four methyl signals including one methoxy group $\left(\delta_{H} 3.55(\mathrm{~s}), 2.16(\mathrm{~s}), 1.57(\mathrm{~s})\right.$ and $\left.1.25(\mathrm{~s})\right)$, one olefinic proton signal $\left(\delta_{H} 5.01\right.$ (br.s), one aromatic proton signal $\left(\delta_{H}\right.$ $6.85(\mathrm{~s}))$ and one methylene proton signal $\left(\delta_{H} 3.41(\mathrm{~d}, J=4.8 \mathrm{~Hz})\right)$. The connectivity of the protons and $\mathrm{C}$-atoms was established by the ${ }^{1} \mathrm{H},{ }^{13} \mathrm{C}$ HSQC spectrum. Further interpretation of HMBC spectrum showed the following long-range correlations (Figure 2): from H-6 to C-2 and C-7, from H-9 to C-3, from $\mathrm{H}-10$ to C-3, C-4 and C-5, from $\mathrm{H}-1^{\prime}$ to $\mathrm{C}-5, \mathrm{C}-6$ and $\mathrm{C}-3^{\prime}$, from $\mathrm{H}-2^{\prime}$ to $\mathrm{C}-5, \mathrm{C}-1^{\prime}, \mathrm{C}-4^{\prime}$ and $\mathrm{C}-5^{\prime}$, from $\mathrm{H}-4^{\prime}$ to $\mathrm{C}-2^{\prime}$ and from $\mathrm{H}-5^{\prime}$ to $\mathrm{C}-2^{\prime}$ and $\mathrm{C}-3^{\prime}$. The above spectral evidences led to the establishment of $\mathbf{1}$ as 5 -( $3^{\prime}$-methyl- $2^{\prime}$-butenyl)-2hydroxy-3-methoxy-4-methylbenzoic acid.

Compound 2 was obtained as white powder that gave a quasimolecular ion peak at $[\mathrm{M}+\mathrm{H}]^{+} \mathrm{m} / z 293.10185$ in the HRESIMS (positive) consistent with a molecular formula of $\mathrm{C}_{15} \mathrm{H}_{16} \mathrm{O}_{6}$ (calcd for $\left.\mathrm{C}_{15} \mathrm{H}_{17} \mathrm{O}_{6}, 293.10196\right)$, requiring eight degrees of unsaturation. The ${ }^{1} \mathrm{H}$ NMR (Table 1) spectrum of 2 contained signals of three methyl signals including one methoxy group $\left(\delta_{H} 3.91(\mathrm{~s}), 2.21(\mathrm{~s})\right.$ and $1.93(\mathrm{~s}))$, one aromatic proton signal $\left(\delta_{H} 7.03(\mathrm{~s})\right)$, which showed the presence of pentasubstituted aromatic ring, one olefinic proton signal $\left(\delta_{H} 6.94(\mathrm{~s})\right)$, which implied the presence of trisubstituted double bond and two oxygenated methylene proton signals $\left(\delta_{H} 5.44(\mathrm{~s})\right.$ and 4.80 (br. s)). From the ${ }^{13} \mathrm{C}$ NMR data, two carboxyl groups $\left(\delta_{C} 172.1\right.$ (s) and $169.4(\mathrm{~s})$ ), three methyl signals including one methoxy group $\left(\delta_{C} 59.0(\mathrm{q}), 12.6(\mathrm{q})\right.$ and $\left.9.4(\mathrm{q})\right)$ and two oxygenated methylene carbon signals $\left(\delta_{C} 69.0(\mathrm{t})\right.$ and $\left.66.0(\mathrm{t})\right)$ were observed. The remaining carbon signals $\left(\delta_{C} 158.6(\mathrm{~s}), 153.1(\mathrm{~s}), 136.0(\mathrm{~d}), 130.4(\mathrm{~s}), 128.6(\mathrm{~s})\right.$, $125.9 \times 2(\mathrm{~s})$ and $101.3(\mathrm{~d}))$ could be assigned to one pentasubstituted aromatic ring and one trisubstituted double bond. The connectivity of the protons and $\mathrm{C}$-atoms was established by the ${ }^{1} \mathrm{H},{ }^{13} \mathrm{C}$ HSQC spectrum. Comparison of the NMR data of 2 with those of $5,{ }^{14}$ a known compound firstly isolated from Alternaria porri, revealed that both compounds possess the same substitution pattern. The distinct differences between $\mathbf{2}$ and $\mathbf{5}$ are that: the chemical shifts value at C-4' of $2\left(\delta_{C} 169.4(\mathrm{~s})\right)$ were absent in $5\left(\delta_{C} 25.8(\mathrm{q})\right)$. In addition, the chemical shift value at $\mathrm{C}-2^{\prime}\left(\delta_{C} 136.0(\mathrm{~d})\right)$ in 2 was shifted downfield compared with $5\left(\delta_{C} 119.2(\mathrm{~d})\right)$ affected by conjugative effect. The chemical shift value at C-5' $\left(\delta_{C} 12.6\right.$ (q)) in 2 was shifted upfield compared with 5 ( $\delta_{C} 18.3$ (q)) owing to shielding effect caused by carboxyl group at $\mathrm{C}^{-} 3^{\prime}$ in 2 . Further interpretation of HMBC spectrum showed the following long-range correlations (Figure 2): from $\mathrm{H}-6$ to $\mathrm{C}-4$ and C-7, from $\mathrm{H}-8$ to C-1, C-3 and C-7, from $\mathrm{H}-9$ to $\mathrm{C}-3$, from $\mathrm{H}-10$ to $\mathrm{C}-3, \mathrm{C}-4$ and $\mathrm{C}-5$, from $\mathrm{H}-1^{\prime}$ to $\mathrm{C}-5$ and $\mathrm{C}-3^{\prime}$, from $\mathrm{H}-2^{\prime}$ to $\mathrm{C}-4^{\prime}$ and from $\mathrm{H}-5^{\prime}$ to $\mathrm{C}-4^{\prime}$. The configuration of the double

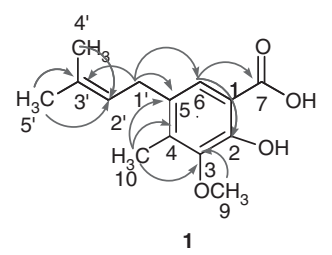

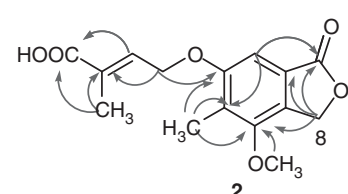

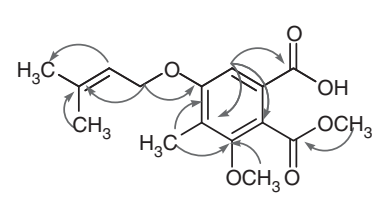

3

Figure 2 Selected HMBC correlations of compounds 1-3. 
bond at C-2 was assigned to be E-orientation because Me-5 characteristic upfield resonance at $\delta_{C} 12.6(\mathrm{q})$ and no NOE correlation observed between $\mathrm{H}-2$ and $\mathrm{H}-5$. In addition, the chemical shift at C-2' $\left(\delta_{H} 6.94\left(1 \mathrm{H}\right.\right.$, br. s); $\left.\delta_{C} 136.0(\mathrm{~d})\right)$ in 1 were shifted downfield comparison chemical shifts with $4\left(\delta_{H} 5.47(1 \mathrm{H}, \mathrm{t}, J=6.7,12.6 \mathrm{~Hz})\right.$; $\delta_{C} 119.3(\mathrm{~d})$ ) owing to deshielding effect of carboxyl group at C- $3^{\prime}$. In light of the evidences mentioned above, the structure of $\mathbf{2}$ was finally established as 5-( $3^{\prime}$-carboxyl-3'-methyl-2E-allyloxy)-3-methoxy-4methylphthalide (2).

Compound 3 had the molecular formula $\mathrm{C}_{16} \mathrm{H}_{20} \mathrm{O}_{6}$, as established from positive ion HRESIMS $[\mathrm{M}+\mathrm{H}]^{+} \mathrm{m} / \mathrm{z} 309.13338$ (calcd for $\mathrm{C}_{16} \mathrm{H}_{21} \mathrm{O}_{6}, 309.13326$ ). The ${ }^{1} \mathrm{H}$ NMR (Table 1) spectrum exhibited one aromatic resonance at $\delta_{H} 7.32(\mathrm{~s})$, which was indicative of a pentasubstituted phenyl ring, and one olefinic proton signal $\left(\delta_{H} 5.47\right.$ (br. s)) exhibited the presence of trisubstituted double bond. In addition, the remaining signals in ${ }^{1} \mathrm{H}$ NMR spectrum assigned to five methyl signals including two methoxy groups $\left(\delta_{H} 3.92(\mathrm{~s}), 3.80\right.$ (s), $2.21(\mathrm{~s}), 1.80(\mathrm{~s})$ and $1.77(\mathrm{~s}))$, and one oxygenated methylene proton signal $\left(\delta_{H} 4.60(\mathrm{~d}, J=6.6 \mathrm{~Hz})\right)$. The 16 carbon signals in the ${ }^{13} \mathrm{C}$ NMR spectrum were sorted by DEPT experiment into five methyls (involving two methoxy groups), two carboxyl carbons, eight olefinic carbons and one oxygenated methylene carbon. The connectivity of the protons and $\mathrm{C}$-atoms was established by the ${ }^{1} \mathrm{H},{ }^{13} \mathrm{C}$ HSQC spectrum. By careful analysis of NMR data, we found that the NMR spectral data of $\mathbf{3}$ was the same as $\mathbf{7}$ except for one additional methoxy group. The additional methoxy group was located at C-8 deduced from the long-range correlation from $\mathrm{H}_{3}-\left(8-\mathrm{OCH}_{3}\right)$ to $\mathrm{C}-8$. Further interpretation of $\mathrm{HMBC}$ spectrum showed the following long-range correlations (Figure 2): from $\mathrm{H}-6$ to C-2, C-4 and C-7, from $\mathrm{H}-9$ to C3 , from $\mathrm{H}-10$ to $\mathrm{C}-3$ and $\mathrm{C}-5$, from $\mathrm{H}-1^{\prime}$ to $\mathrm{C}-5$ and $\mathrm{C}-3^{\prime}$ and from $\mathrm{H}-$ $2^{\prime}$ to $\mathrm{C}-4^{\prime}$ and $\mathrm{C}-5^{\prime}$. Accordingly, the structure of 3 was elucidated as 5 (3',3'-dimethylallyloxy)-2-methoxycarbonyl-3-methoxy-4-methylbenzoic acid.

Comparison of the physicochemical properties with reported data allowed identifying the compounds (4-9) as 5-( $3^{\prime}, 3^{\prime}$-dimethylallyloxy)3-methoxy-4-methylphthalide (4), ${ }^{14}$ zinnimidine (5), ${ }^{14}$ 5-(3',3'-dimethyl allyloxy)-3-methoxy-4-methylphthalide $(6),{ }^{14} 5$-( $3^{\prime}, 3^{\prime}$-dimethylallyloxy)3-methoxy-4-methylphthalic acid $(7),{ }^{15}$ zinniol anhydride $(8)^{16}$ and porriolide (9). ${ }^{17}$

\section{Antifungal activities}

Compounds (1-9) were evaluated for antifungal activities against three plant pathogenic fungi, and the results are shown in Table 2. Compounds (1-9) displayed significant antifungal activities against three fungal strains including Fusarium graminearum, Botrytis cinerea and Phytophthora nicotianae, with MIC values from $50.0-3.1 \mu \mathrm{g} \mathrm{ml}^{-1}$ (the positive control ketoconazole showed MIC values are $\left.3.1 \mu \mathrm{g} \mathrm{ml}^{-1}\right)$.

Table 2 Antifungal activities against three plant pathogenic fungi of compounds (1-9)

$\operatorname{MIC}\left(\mu g \mathrm{~m}^{-1}\right)$

\begin{tabular}{lrrrrrrrrrr} 
Fungal strain & 1 & 2 & 3 & 4 & 5 & 6 & 7 & 8 & 9 & ketoconazole \\
\hline $\begin{array}{l}\text { Fusarium } \\
\text { graminearum }\end{array}$ & 6.3 & 6.3 & 3.1 & 6.3 & 6.3 & 3.1 & 3.1 & 6.3 & 3.1 & 3.1 \\
$\begin{array}{l}\text { Botrytis cinerea } \\
\text { Phytophthora }\end{array}$ & 12.5 & 6.3 & 25 & 12.5 & 6.3 & 25 & 3.1 & 50 & 25 & 3.1 \\
nicotianae & & 6.3 & 6.3 & 6.3 & 6.3 & 6.3 & 6.3 & 6.3 & 6.3 & 3.1 \\
\hline
\end{tabular}

In summary, we have reported the isolation, identification and biological study of nine metabolites from Pestalotiopsis photiniae. All metabolites were structurally related to zinniol, and three of them were identified as new compounds (1-3), whereas six compounds (4-9) have already been reported as being produced by a number of Alternaria species, including A. porri, A. tagetica and A. solani, or synthesized as the major intermediates. Compounds 4, 6 and $\mathbf{8}$ were first reported as the main products resulting from the oxidation of zinniol. ${ }^{16}$ Compound 4 has also been reported previously as a natural compound from A. porri and A. solani, which exhibited no particular inhibitory activity toward lettuce and stone-leek seedlings. ${ }^{16-18}$ Compounds $\mathbf{6}$ and $\mathbf{8}$ displayed no significant phytotoxic activities using leaf-spot assay on marigold leaves. ${ }^{16}$ Compound 5 was firstly isolated from $A$. cichorii which was inactive toward Russian knapweed and the lettuce shoot. ${ }^{12,19}$ Compound 7 was the key intermediate of total synthesis of some phthalides. ${ }^{15}$ According to experimental results reported by R. Suemitsu et al., compound 9 inhibited the root elongation of both lettuce and stone-leek seedlings by 53.3 and $48.5 \%$ at 400 p.p.m., respectively, the toxicity of 9 was rather weak compared with that of porritoxin, which inhibited lettuce seedling growth at a concentration of 10 p.p.m.. ${ }^{17}$ In this paper, compounds (1-9) were evaluated in antifungal activity assay, and the results indicated that compounds (1-9) displayed significant antifungal activities against three fungal strains.

\section{CONFLICT OF INTEREST}

The authors declare no conflict of interest.

\section{ACKNOWLEDGEMENTS}

This work was supported by the programs for New Century Excellent Talents in University (NCET-09-0112), the Key Project of Chinese Ministry of Education and the Key Applied Basic Research Programs of Hebei Province (0996030917D) and National Natural Science Foundation of China (31071701), Hebei Province Science Fund for Distinguished Young Scholars (C2011201113), National Department Public Benefit Research Foundation (201003065) and Project supported by the National High Technology Research and Development Program of China (Grant no. 2011AA10A204).

1 Suryanarayanan, T. S., Senthilarasu, G. \& Muruganandam, V. Endophytic fungi from Cuscuta reflexa and its host plants. Fungal Divers. 4, 117-123 (2000).

2 Strobel, G. A., Hess, W. M., Ford, E., Sidhu, R. S. \& Yang, X. Endophytic fungi in grasses and woody plants. J. Ind. Microbiol. 17, 417-423 (1996).

3 Li, J. Y., Strobel, G. A., Hess, W. M. \& Ford, E. Endophytic taxol-producing fungi from bald cypress, Taxodium distichum. Microbiology 142, 2223-2226 (1996).

4 Liu, L., Liu, S. C., Chen, X. L., Guo, L. D. \& Che, Y. S. Pestalofones A-E, bioactive cyclohexanone derivatives from the plant endophytic fungus Pestalotiopsis fici. Bioorg. Med. Chem. 17, 606-613 (2009).

5 Ding, G., Li, Y., Fu, S. B., Liu, S. C., Wei, J. C. \& Che, Y. S. Ambuic acid and torreyanic acid derivatives from the endolichenic fungus Pestalotiopsis sp. J. Nat. Prod. 72, 182-185 (2009).

$6 \mathrm{Xu}$, J. et al. Chromones from the endophytic fungus Pestalotiopsis sp. isolated from the Chinese mangrove plant Rhizophora mucronata. J. Nat. Prod. 72, 662-665 (2009).

7 Ding, G., Zheng, Z. H., Liu, S. C., Zhang, H., Guo, L. D. \& Che, Y. S. Photinides A-F, cytotoxic benzofuranone-derived ã-lactones from the plant endophytic fungus Pestalotiopsis photiniae. J. Nat. Prod. 72, 942-945 (2009).

8 Liu, L. et al. Chloropestolide A, an antitumor metabolite with an unprecedented spiroketal skeleton from Pestalotiopsis fici. Org. Lett. 11, 2836-2839 (2009).

9 Liu, L., Liu, S. C., Niu, S. B., Guo, L. D., Chen, X. L. \& Che, Y. S. Isoprenylated chromone derivatives from the plant endophytic fungus Pestalotiopsis fici. J. Nat. Prod. 72, 1482-1486 (2009).

10 Yang, X. L., Zhang, S., Zhu, H. J. \& Luo, D. Q. Dihydroberkleasmin A: a new eremophilane sesquiterpenoid from the fermentation broth of the plant endophytic fungus Pestalotiopsis photiniae. Molecules 16, 1910-1916 (2011).

11 Fukami, A. et al. A new antiinfluenza virus antibiotic, 10-norparvulenone from Microsphaeropsis sp. FO-5050. J. Antibiot. 53, 1215-1218 (2000).

12 Andrea, S., Joseph, H. \& Gary, S. Zinniol-related phytotoxins from Alternaria cichorii. Phytochemistry 32, 1145-1149 (1993). 
13 Ding, G., Jiang, L. H., Guo, L. D., Chen, X. L., Zhang, H. \& Che, S. Y. Pestalazines and pestalamides, bioactive metabolites from the plant pathogenic fungus Pestalotiopsis theae. J. Nat. Prod. 71, 1861-1865 (2008).

14 Rikisaku, S., Keiichiro, O., Yoshiyuki, M. \& Shigemi, N. Zinnimidine and 5-(3, 3dimethylallyloxy)-7-methoxy-6-methylphthalide from Alternaria porri. Phytochemistry 38, 495-497 (1995).

15 Hariprakasha, H. K. \& Subbarao, G. S. R. Synthesis of some naturally occurring phthalides from Alternaria species. Indian J. Chem. Sect. B Org. Chem. Incl. Med. Chem. 37, 851-856 (1998).

16 Gamboa-Angulo, M. M., Escalante-Erosa, F., García-Sosa, K., Alejos-González, F., Delgado-Lamas, G. \& Peña-Rodríguez, L. M. Natural zinniol derivatives from Alternaria tagetica. Isolation, synthesis, and structure-activity correlation. J. Agric. Food Chem. 50, 1053-1058 (2002).

17 Suemitsu, R., Ohnishi, K., Horiuchi, M., Morikawa, Y., Sakaki, Y. \& Matsumoto, Y. Structure of porriolide, a new metabolite from Alternaria porri. Biosci. Biotechnol. Biochem. 57, 334-335 (1993).

18 Gamboa-Angulo, M. M., Alejos-González, F. \& Peña-Rodríguez, L. M. Homozinniol, a new phytotoxic metabolite from Alternaria solani. J. Agric. Food Chem. 45, 282-285 (1997).

19 Horiuchi, M. et al. A novel isoindoline, porritoxin sulfonic acid, from Alternaria porri and the structure-phytotoxicity correlation of its related compounds. Biosci. Biotechnol. Biochem. 67, 1580-1583 (2003). 